\title{
Sinkretisme Budaya Jawa dan Islam dalam Gamitan Seni Tradisional Janengan
}

\author{
Wawan Hernawan ${ }^{1,}$, Tatang Zakaria ${ }^{2}$, Aini Rohmah ${ }^{3}$ \\ 1 UIN Sunan Gunung Djati Bandung, Indonesia; Email: wawanhernawan@uinsgd.ac.id \\ 2 UIN Sunan Gunung Djati Bandung, Indonesia; Email: tatangzakaria@uinsgd.ac.id \\ 3 UIN Sunan Gunung Djati Bandung, Indonesia; Email: ainirohmah@gmail.com \\ * Correspondence
}

Received: 2020-06-16; Accepted: 2020-08-04; Published: 2020-08-29

\begin{abstract}
The purpose of this research is to explore the practice of syncretism in Janengan traditional art in Kesugihan Village, Cilacap, Central Java. This study employs a qualitative research with a multidisciplinary approach contained four historical method stages. The result of the research shows that Janengan traditional art in Kesugihan Village Cilacap is known as salawat Janengan or salawat illau. It contains Islamic teachings about faith and tasawuf (Islamic mysticism) combined with Javanese local cultural patterns. The community perform this traditional art in slametan events, especially at the commemoration of the Prophet's Birthday (Maulid Nabi Saw.). In conclusion, the syncretism of Javanese-Islamic culture in syi'ir or salawat singir with the Javanese genre as well as sajen (offerings) in each of these arts is strong. This study recommends conducting policy research in strengthening the preservation of Javanese-Islamic traditional arts and Indonesian contexts.
\end{abstract}

Keywords: Javanese-Islamic; singiran; syncretism; traditional-arts.

Abstrak: Tujuan penelitian ini untuk menggamit sinkretisme dalam seni tradisional Janengan di Desa Kesugihan, Cilacap, Jawa Tengah. Jenis penelitian kualitatif ini menggunakan pendekatan multidisipliner dengan empat tahapan metode sejarah. Hasil penelitian dan pembahasan adalah seni tradisional Janengan yang dijumpai di Desa Kesugihan Cilacap dikenal dengan Salawat Janengan atau Salawat Illau berisi ajaran Islam tentang akidah dan tasawuf yang dipadukan dengan pola budaya lokal Jawa. Seni tradisional ini ditampilkan pada acara slametan dan terutama pada peringatan maulid Nabi Saw. Kesimpulan penelitian adalah kuatnya sinkretisme budaya Jawa-Islam pada syair atau singir salawat dengan genre Jawa serta sajen (sesaji) pada setiap kesenian itu digelar. Penelitian ini merekomendasikan untuk dilakukan penelitian kebijakan dalam memperkuat kelestarian seni tradisional Jawa-Islam dan Indonesia.

Kata Kunci: Jawa-Islam; seni-tradisional; singiran; sinkretis

\section{Pendahuluan}

Seni tradisional khususnya di Jawa memiliki kekhasan sendiri karena seringkali digunakan dalam penyebaran agama Islam. Sebelum digunakan sebagai media dakwah seni tradisional tersebut sudah dilaksanakan dalam ritual kemasyarakat tertentu. Bahkan menurut Purnata (1977) bahwa ritual keagamaan melahirkan berbagai bentuk kesenian, dan kesenian yang tumbuh tersebut merupakan kreativitas yang spontan dari masyarakat yang bertujuan untuk ibadah kepada Tuhan. Fungsi seni dalam penyebaran agama bisa terlihat seperti pada Wayang (Anggoro, 2018; Habibi, 2016), Debus (Said, 2016), Terebang (Fauzan \& Nashar, 2017) dan ada juga dalam bentuk seni rupa (Supatmo, 2016; Supatmo \& Syafii, 2019).

Perpaduan antara agama dan seni juga terjadi pada seni tradisional Janengan di Cilacap. Seni tradisional ini sepintas dapat dipandang sebagai seni khas Islam, namun nuansa kekhasan Jawanya tetap terasa kuat. Seni tradisional Janengan dalam sejumlah hal mirip dengan seni rebana, hadrah, qasidah, 
atau nasyid. Karena memang genre musik itulah yang diduga kuat menjadi cikal bakal lahirnya seni tradisional ini. Pada perkembangannya, Janengan menjadi seni tradisi Islam-Jawa yang diwariskan secara turun-temurun dan memiliki keunikan tersendiri (Fatkhurrohman \& Susetyo, 2017).

Disebut unik, meskipun hanya diiringi alat musik sederhana, yaitu: kendang, kempul, kempreng, kentung, terbang, gong, dan kecrek, namun singir salawat yang dilantunkan dibawakan dengan nada sangat tinggi dan melengking (Junaidi, 2013). Karena itu, untuk melantunkannya hanya dapat dilakukan oleh orang-orang khusus yang terbiasa (Junaidi, 2013). Waktu pentasnya pun dapat dikatakan unik juga. Seni tradisional ini tidak dipentaskan pada sembarang waktu. Tetapi, hanya pada hari Kamis malam Jumat, mulai pukul 22.00 WIB. Waktu pentasnya terkadang hanya sampai tengah malam, namun tidak jarang semalam suntuk (Rohmah, 2019). Keunikan lainnya, setiap singir salawat Janegan dinyanyikan bisa lebih dari satu jam (Rohmah, 2019).

Namun demikian, disamping serba unik, seni tradisional Janengan juga sarat dengan praktik sinkretisme yang dalam studi agama-agama dimaknai sebagai pencampuran gagasan-gagasan dan praktik-praktik keagamaan tertentu (Amin, 2000; Brakel, 2004). Masih dalam pandangan studi agamaagama, sinkretisme juga dimaknai sebagai konsep yang digunakan untuk membahas keterkaitan sistematik di antara unsur-unsur tradisi yang beragam (Amin, 2000). Kata "keterkaitan" di sini tentu tidak dimaksudkan untuk penyatuan unsur-unsur, tetapi lebih kepada tataran objek-objek sinkretis yang diteliti yang dipandang sebagai jati diri kebudayaan khas sebagai akibat adanya percampuran gagasan dan praktik agama dengan tradisi lokal. Hal lain, sinkretisme yang dimaksud di sini mengandung pengertian, bahwa unsur utama adalah Islam. Sedangkan budaya lokal (Jawa) dijadikan sebagai unsur tambahan yang menyebabkan unsur utama mengalami penyesuaian dan bahkan pemudaran (Rohmah, 2019). Karena itu, ke-Jawa-an bisa disebut sebagai unsur lain atau unsur eksternal. Penelitian ini juga sealur dengan persepektif sejenis yang sering dijadikan pola dalam studi yang berkaitan dengan topik sinkretisme dalam hubungannya antara Jawa dan Islam. Adalah fakta historis, bahwa dalam bentuknya yang formal, masyarakat yang memiliki orientasi Jawa memperlihatkan sikap akomodatif terhadap nilai-nilai Islam (Irianto, 2016). Sinkretisme sebagai sebuah objek penelitian dimaksudkan untuk melihat hubungan Jawa dan Islam sebagai sebuah objek menarik untuk diteliti (Irianto, 2016).

Penelitian mengenai hubungan seni dan agama sudah banyak yang melakukan. Saihu (2020) menemukan bahwa seni tradisional bisa berfungsi dalam merajut harmoni di masyarakat. Sementara itu, Murtana (2011) menyebutkan bahwa seni merupakan manifestasi ajaran agama dalam kehidupan sehari-hari. Karena seni merupakan manifestasi ajaran agama, maka banyak kesenian tradisional berkembang dengan nilai-nilai keagamaan, seperti: seni pertunjukan Randai di Minagkabau (Bahardur, 2018), Seni Seudati di Aceh (Hasan, 2013), Seni Debus di Banten (Said, 2016; Sulastri, 2014), Wayang (Anggoro, 2018; Habibi, 2016), Terebang (Fauzan \& Nashar, 2017) dan ada juga dalam bentuk seni rupa (Supatmo, 2016; Supatmo \& Syafii, 2019).

Kajian mengenai sinkretisme pada kesenian tradisional juga bukanlah hal yang baru. Penelitian mengenai sinkretisme pada lagu dilakukan oleh Ahmed (2015) akibat pengaruh dari budaya Barat, Melayu dan India (Ahmed, 2015). Unsur sinkretisme juga terjadi pada Budaya Jampi di Deli (Syarfina, 2011). Penelitian lain yaitu unsur sinkretisme juga terjadi pada kesenian Gamelan Kromong di Sumedang (Sutisna, Suganda, Dienaputra, \& Guna, 2019). Terkait dengan seni tradisional Janengan beberapa penelitian sebelumnya. Penelitian seni Janengan sebagai suatu seni tradisional khas Islam Jawa yang merupakan perpaduan tiga unsur tradisi musik, yakni tradisi musik Jawa, tradisi musik Islam Timur Tengah (Arab) dan Barat sudah dilakukan oleh Junaidi (Junaidi, 2013) dan dari sisi analisis musiknya dilakukan oleh Fatkhurrohman \& Susetyo (Fatkhurrohman \& Susetyo, 2017). Penelitian Rochsun (2018) mengungkapkan bahwa Seni Janengan merupakan media pertukaran informasi masyarakat terkait dengan keluarga, pertanian, dan peternakan. Selain itu Janengan juga dilakukan oleh masyarakat Jawa yang tinggal di daerah transmigrasi seperti pada penelitian Fitrianto (2017). Pada masyarakat transmigran, Janengan berfungsi meneguhkan identitas etnis Jawa tersebut. Dari beberapa penelitian tersebut, belum ada yang meneliti unsur sinkretisme yang ada pada seni Janengan. 
Penelitian ini sangat penting, yaitu bukan hanya sebuah refleksi kesadaran dari pentingnya pelajaran historis dari asal-usul peristiwa itu, tetapi juga menunjukkan keinsafan bersama dalam mencari solusi bersama, serta bekerja secara bersama-sama tentang kehidupan bersama dalam pelestarian suatu kebudayaan bersama (Miharja \& Hernawan, 2017). Kendatipun dalam tahap-tahap tertentu sering berakhir dengan kekurangakuratan dalam menjelaskan catatan historis, melalui penelitian ini diharapkan mampu menyuarakan keindahan seni tradisional Janengan, sehingga dapat dinikmati oleh khalayak masa kini dan yang akan datang (Hernawan \& Kusdiana, 2020). Hal lain, penelitian ini juga penting dilakukan mengingat seni tradisional Janengan bagi masyarakat Kesugihan Cilacap yang bukan sekedar warisan budaya turun-temurun, namun merupakan bagian dari rangkaian fakta historis Islamisasi yang terjadi di sana.

Penelitian ini tentu tidak akan menyajikan seluruh perspektifnya tentang seni tradisional Janengan di Desa Kesugihan Cilacap, terutama menyangkut hal-hal yang diluar nalar historis, sesuai bidang keahlian peneliti. Akan tetapi, berupaya memfokuskan kepada aspek historis seni tradisonal tersebut di sana, tata laksananya, serta perilaku sinkretis dalam tahapan-tahapannya. Tema historis, tatalaksana, dan perilaku sinkretis dijadikan objek penelitian dengan harapan untuk mengetahui posisi individu, masyarakat, dan instansi pemerintah di tengah kekhawatiran kegagalan regenerasi seniman tradisional Janengan. Regenerasi terjadi, ketika beberapa pihak memiliki kesadaran bersama, untuk mencari solusi bersama, serta bekerja secara bersama-sama tentang pelestarian suatu kebudayaan masyarakat (Miharja \& Hernawan, 2017). Penelitian ini memberikan sumbangan teoretis, yaitu diharapkan dapat bermanfaat bagi perkembangan studi sejarah dan pelestarian seni tradisional, khususnya sejarah seni tradisional. Sedangkan secara lebih luas, hasil penelitian ini dapat dijadikan kerangka acuan bagi penelitian lanjutan berupa penelitian kebijakan guna memperkuat kelestarian seni tradisional Jawa-Islam dan Indonesia.

Jenis penelitian yang digunakan adalah kualitatif dengan pendekatan multi-disipliner. Penggunaan pendekatan multi-disipliner, mengingat kajian yang dihadapi memerlukan sejumlah pendekatan berbeda untuk memperkaya kajian (Hernawan, 2014). Sedangkan metode yang dipakai adalah empat tahapan dalam metode sejarah, yaitu: heuristik, kritik, interpretasi, dan historiografi (Hernawan, 2014).

\section{Sinkretisme dan Seni}

Secara etimologi, sinkretisme berasal dari kata sun atau synkretismos (Yunani), yang berarti perserikatan, kebersamaan (Kraemer, 1954; Martin, 1996). Ada juga yang menyebut sinkretisme berasal dari kata syin dan kretiozein atau kerannynai, yaitu mencampurkan sejumlah komponen yang paradok (Aldyan, 2020). Sementara sinkretisme dalam beragama, Mulder memberi batasan sebagai upaya menghilangkan beragam diskrepnasi guna mewujudkan kesatuan di antara varian aliran keagamaan melalui diktum dan dogma baru (Mulder, 1999). Bagi Mulder, seorang penganut sinkretis mengakui bahwa seluruh agama adalah baik dan benar (Mulder, 1999). Praktik keagamaan seperti itulah yang kemudian dijumpai pada sebagian masyarakat Jawa-Islam. Mereka mengakui Islam sebagai agama yang menjadi kepenganutannya, namun prinsip-prinsip pokoknya tidak dilaksanakan sepenuhnya. Prinsip-prinsip pokok dimaksud, seperti: salat, puasa, zakat, dan haji (Koenjaraningrat, 1994). Sinkretisme beranggapan, bahwa Islam tidak lagi tampil dalam unsur yang asli, tetapi sudah tercampur dengan unsur-unsur yang sifatnya eksternal. Pada perkembangannya, bahwa Islam sinkretis digambarkan sebagai suatu genre keagamaan yang sudah jauh dari sifat aslinya (yang murni) dari tempat asalnya, yaitu Timur Tengah (Wahyono, 2001). Perilaku sinkretisme dalam masyarakat Jawa-Islam dapat berupa memadukan dua agama atau lebih, yaitu: Hindu, Budha, Çiva-Budha (Budhaperwa), tradisi lokal, dengan Islam. Melalui perpaduan tersebut kemudian memengaruhi mindset keyakinan mereka, meliputi: konsep kosmogoni, kosmologi, termasuk silsilah para raja Mataram. Perilaku sinkretis lainnya pada masyarakat Jawa-Islam dapat dijumpai dalam ritual, seperti: midodareni, brokohan atau sepasaran, do'a, maupun mantra (Rohmah, 2019).

Sementara seni, secara etimologi berasal dari kata genie (Latin), merujuk kepada kepandaian yang tidak terukur. Melalui kata itu kemudian berkembang menjadi genious (Pamadhi, 2012). Pendapat lain, 
kata seni bukan berasal dari Bahasa Latin, tetapi dari Bahasa Belanda genie, yaitu kemampuan luar biasa sejak lahir (Sarwono, 2017). Pengertian inilah yang kemudian memengaruhi keyakinan sebagian orang, bahwa keahlian seni merupakan anugerah yang diwariskan (Purwanto, 2016). Pada pengertian yang lain, seni sering dihubungkan dengan ekspresi jiwa dan perwujudan keindahan (Sarwono, 2017). Dikatakan, seni dan keindahan ibarat dua sisi mata uang. Meskipun berbeda, tetapi tidak dapat dipisahkan satu sama lain. Keindahan rasa yang diekspresikan dalam berbagai medium inilah yang kemudian menjadi salah satu rahasia pendedahan seni selalu menarik perhatian (Sarwono, 2017).

Adapun istilah seni tradisional atau ada juga yang menyebut kesenian pribumi, secara istilah merupakan hasil karya yang telah dianggit oleh nenek moyang yang hingga hari ini masih dipentaskan masyarakat modern (Irianto, 2016). Seni tradisional merupakan bagian dari gaya seni yang telah dinikmati oleh masyarakat, lahir dan berkembang dari lingkungan mereka. Tujuan awal dibentuknya seni tradisional, dapat diduga, merupakan media hiburan bagi masyarakat kelas bawah (Irianto, 2016). Dugaan itu cukup beralasan, karena dalam sejumlah hal merupakan interpretasi tradisi dari unsurunsur tradisional masyarakat pada kawasan terbentuknya seni tradisional itu. Pada gilirannya, seni tradisional akan mudah diterima oleh masyarakat sebagai warisan tradisi yang diwariskan nenek moyang kepada generasi penerusnya (Lindsay \& Kitsch, 1991). Karena itu pula, tidak jarang pada seni tradisional menghadirkan unsur-unsur dan simbol-simbol budaya lokal dalam rangka membentuk identitas kelompoknya (Lindsay \& Kitsch, 1991). Itulah yang diduga kuat terjadi pada seni tradisional Janengan di Desa Kesugihan, Kecamatan Kesugihan, Kabupaten Cilacap, Jawa Tengah. Meskipun bergenre salawat, namun rasa lokalitas Jawa dengan nuansa budaya lokal khas Kesugihan masih dirasakan sangat kuat.

\section{Seni Janengan di Cilacap}

\section{Riwayat Seni Tradisional Janengan}

Secara umum, Desa Kesugihan, Kecamatan Kesugihan, Kabupaten Cilacap yang dijadikan tempat penelitian seni tradisional Janengan dikenal sebagai kota santri. Disebut kota santri, karena terdapat 6 (enam) pondok pesantren (ponpes). Keenam pondok pesantren tersebut, masing-masing: Manarul Huda, Assasunnajah, Apik, Al-Fiel, 'Ainul Huda, dan Al-Ihya Ulumaddin. Pondok pesantren yang disebut terakhir didirikan pada 24 November 1925 M./1344 H., oleh K.H. Badawi Hanafi, dikenal pondok pesantren Kesugihan. Pondok pesantren Al-Ihya Ulumaddin kini berdiri megah di Jl. Kemerdekaan Timur No.16, Desa Kesugihan Kidul, Kecamatan Kesugihan, Kabupaten Cilacap, Provinsi Jawa Tengah. Pada perkembangannya sekarang, pondok pesantren Al-Ihya Ulumaddin termasuk urutan ke sembilan dalam daftar pondok pesantren terbesar di Indonesia (Gus Toha, wawancara pribadi, 26 April 2019).

Menelusuri riwayat seni tradisional Janengan, dari beberapa informasi yang berhasil dikumpulkan, bukan asli berasal dari Desa Kesugihan. Seni tradisional itu diciptakan oleh kyai Jamjami, seorang da'i asal Kebumen (Junaidi, 2013). Namun demikian, kyai Jamjami hingga wafatnya tidak memberi nama kepada jenis kesenian itu. Masyarakat Kebumen kemudian menyebutnya Jamjaneng yang dihubungkan kepada nama penciptanya, kyai Jamjami (Junaidi, 2013). Seni tradisional Jamjaneng seiring perjalanan waktu semakin mendapat tempat di masyarakat. Grup-grup seni tradisional ini bermunculan di beberapa daerah Jawa tengah. Tidak jarang seni tradisional ini mengambil bagian dalam rangkaian upacara slametan dan terutama pada perayaan Maulid Nabi Saw., sehingga menjadi bagian dari kesenian khas masyarakat midden of Java. Masyarakat pun menyebutnya dengan Jamjanian. Seni tradisional Jamjanian lama-kelamaan oleh masyarakat Jawa diubah menjadi Jamjanen. Pada perkembangannya pula pelafalan Jamjanen, karena dipandang angel (sulit) oleh masyarakat Jawa (terutama masyarakat Kesugihan Cilacap), kemudian dipendekan menjadi Janengan (Gus Toha, wawancara pribadi, 26 April 2019).

Seni tradisional Janengan mulai dikenalkan secara khusus kepada masyarakat Kesugihan oleh pendiri Pondok Pesantren Al-Ihya Ulumaddin, K.H. Badawi Hanafi. Tujuannya agar ada hiburan bagi santri sekaligus syi'ar pondok pesantren Al-Ihya Ulumaddin kepada masyarakat. Usaha kyai tidak sia- 
sia. Pondok pesantren Al-Ihya Ulumaddin semakin dikenal dan menarik perhatian banyak orang. Para santri pun mulai berdatangan dari berbagai daerah, termasuk dari Priangan Timur. Setelah K.H. Badawi Hanafi wafat, seni tradisional Janengan dikembangkan oleh putranya, K.H. Mustholih Badawi (Gus Toha, wawancara pribadi, 26 April 2019). Bagi masyarakat Desa Kesugihan, karena seni tradisional Janengan lebih berupa singir salawat kemudian disebut salawat Janengan atau disebut pula salawat illau. Terdapat dugaan, disebut salawat illau diambil dari kata Illallah. Lagi-lagi, diduga, pada awal berkembangnya seni tradisional Janengan, masyarakat Desa Kesugihan kesulitan menyebut kata Illallah, sebagaimana yang diajarkan para kyai di sana. Karena itu, dengan tanpa bermaksud mengubah makna dan tujuan dari kata itu, mereka menyingkatnya menjadi illau, sebagai ungkapan dzikir (mengingat) Allah Swt. (Solihun, wawancara pribadi, 26 April 2019).

Dalam banyak hal, terutama dari sisi alat musik yang digunakan, seni tradisional Janengan atau salawat Janengan merupakan perpaduan antara musik tradisonal Jawa dan Timur Tengah (Islam) (Junaidi, 2013). Genre yang diusung lebih kepada syi'ir atau singiran salawat yang mengajarkan tentang nilai-nilai ajaran Islam dalam bentuk musikal, nilai kultural, dan nilai religious yang berkaitan dengan aqidah (tata keimanan, tauhid), dan tasawuf (akhlak, mistisisme) (Junaidi, 2013). Pada masa-masa awal syi'ir sawalat atau singiran Janengan ditulis dalam huruf Arab Pegon. Pada perkembangannya sekarang syi'ir sawalat atau singiran Janengan sudah dialihaksarakan ke dalam huruf latin. Suatu kekhasan dalam syi'ir sawalat atau singiran Janengan dilantunkan menggunakan suara yang keras dan tinggi, ragam dialek Jawa, serta nada Jawa yang sangat kental (Sodik, wawancara pribadi, 26 April 2019).

\section{Pementasan Seni Tradisional Janengan}

Sejak pertama diperkenalkan oleh K.H. Badawi Hanafi, pentas seni tradisional Janengan tidak dilakukan pada siang hari dan di sembarang waktu. Sebagai hiburan bagi santri dan masyarakat, kyai mementaskan seni tradisional itu pada hari Kamis malam Jum'at (Sodik, wawancara pribadi, 26 April 2019). Hal itu dilakukan berdasarkan keyakinan jumhur ahl-sunnah wa al-jama'ah, bahwa kata jumu'ah bermakna berkumpul (Taman \& Maqosid, 2008). Jum'at, dalam keyakinan kaum Muslim merupakan sayyidul ayyam atau pemimpin para hari dan tempat berkumpulnya manusia. Hari Jum'at menjadi hari mulia, karena pada hari itu diyakini terdapat peristiwa penting, yaitu Allah Swt., menciptakan Nabiyallah Adam As. Beberapa peristiwa lain, baik yang sudah terjadi maupun menurut berita Alquran disebut terjadi pada hari Jum'at (Taman \& Maqosid, 2008). Atas pemahaman dan keyakinan itulah, kuat dugaan, secara rutin K.H. Badawi Hanafi mementaskan seni tradisonal Janengan pada setiap hari Kamis malam Jum'at. Sementara waktunya mulai dari pukul 20.00 hingga dini hari, sekitar pukul 03.00 WIB (Sodik, wawancara pribadi, 26 April 2019).

Namun seiring perjalanan waktu, meskipun seni tradisional ini pernah mengalami masa-masa subur, keberadaannya kini mulai terkikis oleh seni modern yang menjadikan anak-anak muda kurang tertarik dengan seni tradisional ini (Irianto, 2016). Hal lain, berkesenian seni tradisional Janengan dipandang sulit oleh anak-anak muda sekarang, terutama untuk menjadi vokalis ( $k i$ dalang) perlu menguasai teknik nada suara tinggi dan keras melengking. Itulah yang diduga kuat ikut menambah daftar kesulitan seni tradisional ini dapat dipelajari dengan cepat oleh generasi muda sekarang (Sodik, wawancara pribadi, 26 April 2019). Menyadari hal itu, saat ini seni tradisional Janengan tidak lagi dipentaskan secara rutin pada setiap Kamis malam Jum'at. Akan tetapi, hanya pada Peringatan Hari Besar Islam (PHBI), seperti: peringatan Maulid Nabi dan Isra' Mi'raj. Pementasannya pun hanya dilakukan di Pondok Pesantren Al-Ihya Ulumaddin atau ketika diundang pada acara pernikahan dan slametan warga Desa Kesugihan atau warga tetangga Desa. Waktu pentas pun dimulai pukul 22.00 WIB., sampai tengah malam atau semalam suntuk tergantung si pengundang (Sodik, wawancara pribadi, 26 April 2019).

Seni tradisional Janengan atau salawat Janengan merupakan seni musik yang diiringi oleh alat musik, berupa: kendang, terbang, kempul, kemprêng, kentrung, gong, dan kecrek. Untuk satu pertunjukan seni tradisional Janengan dimainkan oleh sepuluh orang, termasuk seorang vokalis yang merangkap sebagai dalang (orang yang mengatur, merencanakan, dan memimpin suatu pertunjukan atau pentas). 
Dalam seni tradisional Janengan, seorang vokalis sering disebut $k i$ dalang. Berikut ini para pemain kelompok seni tradisional Janengan di Desa Kesugihan:

1. Solihun sebagai vokalis atau dalang pertama,

2. Sodik sebagai ketua kelompok seni tradisional Janengan,

3. Ngatno sebagai penabuh gong,

4. Sobari sebagai penabuh terbang,

5. Kasino sebagai penabuh kempul,

6. Mastur sebagai penabuh kempreng,

7. Ansori sebagai penabuh kentrung atau calung,

8. Evi sebagai penabuh kecrek,

9. Bakir sebagai penabuh kendang,

10. Gus Toha sebagai vokalis atau dalang kedua dan tokoh agama di Desa Kesugihan.

Beberapa hari sebelum pentas seni tradisional Janengan atau salawat Illau, para pemain terlebih dahulu melakukan gurah. Tujuannya untuk menghilangkan lendir, dahak, dan racun di tenggorokan, hidung, paru-paru, serta saluran napas. Dengan demikian, ketika pentas suara mereka menjadi nyaring alami (Solihun, wawancara pribadi, 26 April 2019). Pada saat pentas berlangsung pun sering disediakan cabe rawit, kencur, atau bawang merah yang disajikan bersama sajen (sesaji) seperti pada gambar 1. Para pemain percaya, bahwa dengan makan cabe rawit dan bawang merah akan merasakan pedas yang membuat suara semakin keras. Sementara dengan makan kencur, tenggorokan akan terasa lebih lega (Solihun, wawancara pribadi, 26 April 2019). Hal lain yang tidak boleh diabaikan, dalam mementaskan seni tradisional Janengan atau salawat Illau, para pemain menggunakan kostum berupa pakaian koko atau gamis lengkap dengan penutup kepala (songkok atau kopiah). Pementasan oleh para pemain yang berjumlah sepuluh orang dilakukan sambil bersila pada alas tikar atau karpet dengan alat musik di depannya sesuai jenis alat musik tabuhannya masing-masing (Gus Toha, wawancara pribadi, 26 April 2019).

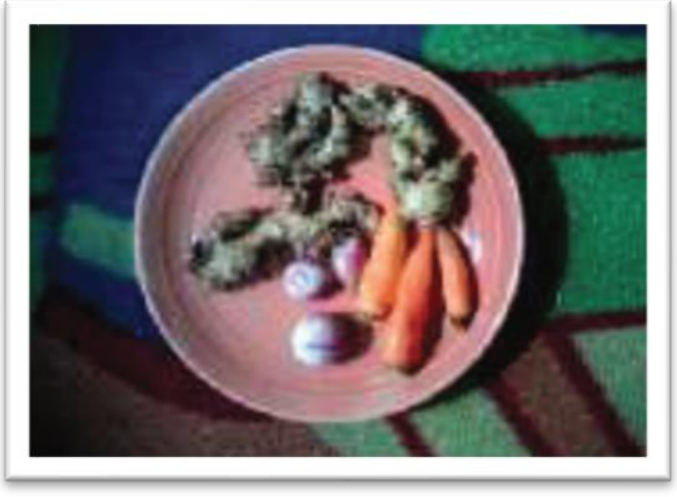

Gambar 1 Kencur, Cabe Rawit, dan Bawang Merah sebagai Sajen Para Pemain

Dalam pementasan seni tradisional Janengan para pemain duduk bersila dan melingkar seperti pada gambar 2 dan setiap bagiannya selalu dimulai dengan solo vocal (Gus Toha, wawancara pribadi, 26 April 2019). Selanjutnya disusul oleh tabuhan kendang dan alat musik lainnya. Ki dalang atau vokalis dalam membawakan syi'ir atau singir, lirik yang dinyanyikan selalu dengan tehnik ngelik. Sebutan ngelik dalam seni tradisional ini adalah menggunakan nada tinggi dan melengking. Dalam melantunkan syi'ir atau singir Janengan dilakukan secara bersama-sama, yaitu dalang pertama, dalang kedua, dan semua penabuh alat musik lainnya. Karena itu, suara yang dihasilkan menjadi meriah seperti saling bersahutan. Sebelum satu lagu selesai biasanya kalimat syi'ir atau singir berikutnya sudah masuk dengan suara yang lebih keras. Hal itu dilakukan hingga satu syi'ir atau singir selesai. Karena itu, durasi untuk satu syi'ir atau singir bisa sampai satu jam atau lebih (Solihun, wawancara pribadi, 26 April 2019). 


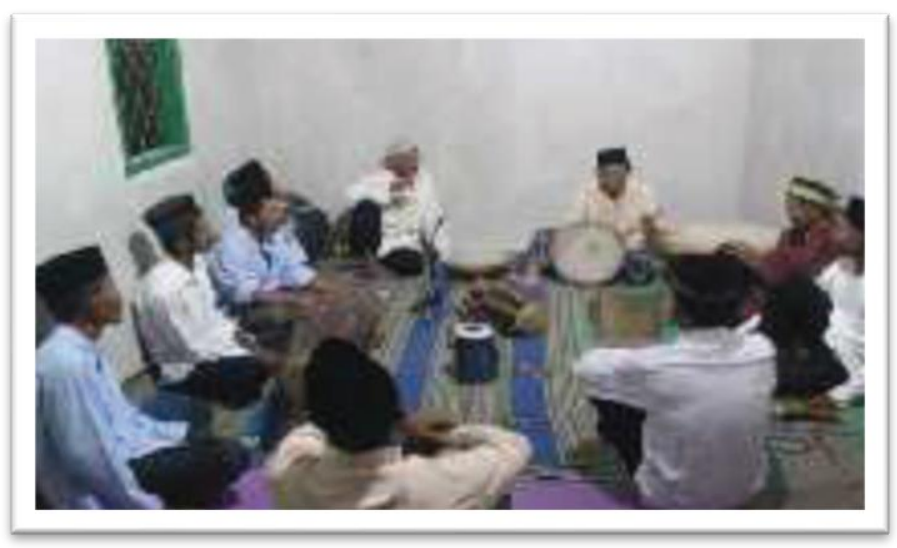

Gambar 2 Para Pemain Sedang Duduk Bersila

\section{Ragam Alat Musik Janengan}

Ragam alat musik seni tradisional Janengan adalah alat-alat musik yang digunakan secara turuntemurun antar generasi di Desa Kesugihan untuk mengiringi syi'ir atau singir salawat Janengan (Bakir, wawancara pribadi, 27 April 2019). Dari sisi fungsi, alat-alat musik seni tradisional Janengan tidak hanya sebagai pengiring sebuah pementasan, tetapi sebagai bukti sejarah maupun sarana edukasi bagi masyarakat ketika itu yang terus dilestarikan keberadaan dan penggunaannya sampai saat ini (Bakir, wawancara pribadi, 27 April 2019). Berikut uraian mengenai alat-alat musik seni tradisional Jenengan dan cara memainkannya:

\section{Kendang}

Kendang merupakan alat musik yang sering digunakan untuk menggelar pertunjukanpertunjukan yang mengangkat tema masyarakat Jawa. Kendang merupakan alat musik khas Jawa (Jawa Barat, Jawa tengah, dan Jawa Timur) yang dimainkan dengan cara dipukul, baik oleh telapak tangan atau alat pemukul khusus (Gambar 3). Kendang dalam seni tradisional Janengan adalah satusatunya alat musik yang dalam tabuhannya dapat melakukan improvisasi (Sodik, wawancara pribadi, 26 April 2019). Sama seperti bentuk kendang pada umumnya, bentuk kendang yang digunakan pada seni tradisional Janengan berbetuk tabung dengan dua sisi. Satu sisi besar untuk menghasilkan bunyi "dhang", sedangkan sisi yang satunya bentuknya kecil yang menghasilkan bunyi "tak" dan "thung". Biasanya kendang terbuat dari kayu nangka dan kulit sapi. Keterampilan improvisasi penabuh kendang sangat diperlukan agar pementasan seni tradisional Janengan tidak monoton dan membosankan (Bakir, wawancara pribadi, 27 April 2019).

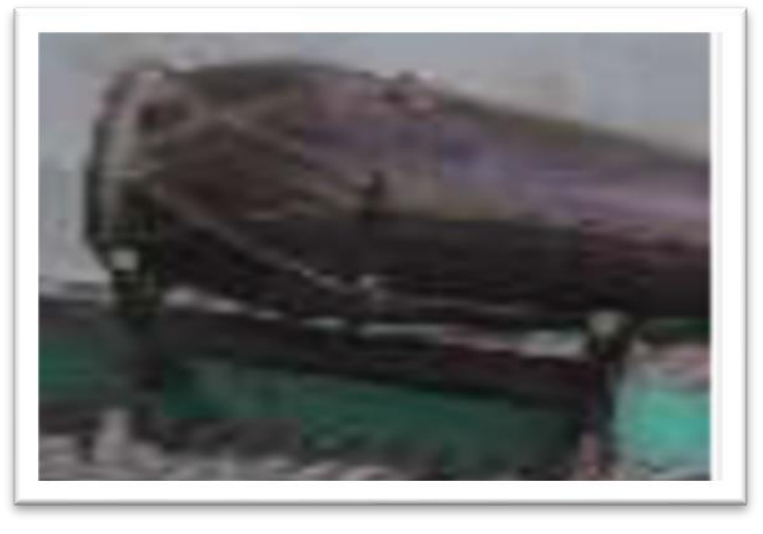

Gambar 3 Alat Musik Kendang

Sumber: Dokumen Peneliti 


\section{Kempul dan Kempréng}

Alat musik kempul dan kempréng (Gambar 5 dan 6) sepintas hampir sama dengan alat musik gong yang digunakan pada seni tradisional Janengan. Perbedaan keduanya terletak pada ukurannya. Diameter kempul lebih kecil apabila dibandingkan dengan gong. Hal yang sama dengan kempréng, ukuran diameternya lebih kecil dari kempul. Cara memainkan kempul dan kempréng adalah dengan cara dipukul oleh telapak tangan pada bagian pinggir dari membrannya (Bakir, wawancara pribadi, 27 April 2019).

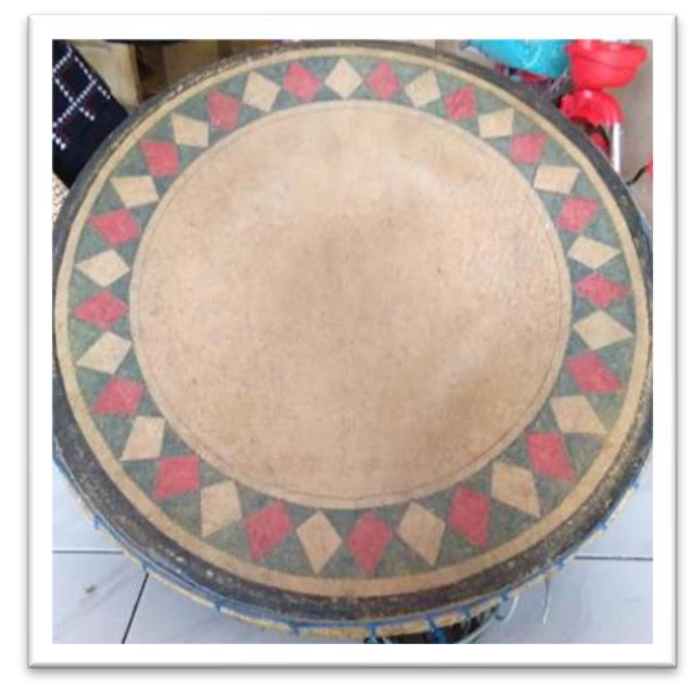

Gambar 4 Alat Musik Kempul Sumber: Dokumen Peneliti

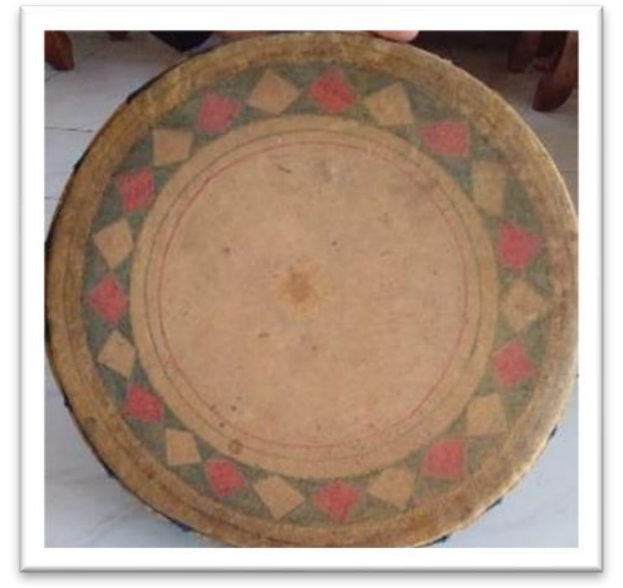

Gambar 5 Alat Musik Kempréng Sumber: Dokumen Peneliti

\section{Kentrung}

Alat musik kentrung (gambar 6) terdiri dari dua buah bambu utuh yang dibentuk mirip alat musik calung (Sunda) dengan panjang sekitar $30 \mathrm{~cm}$. Perbedaannya, kalau calung dimainkan dengan cara dijinjing, sementara kentrung diletakan di lantai. Alat musik kentrung dimainkan dengan cara dipukul menggunakan pemukul khusus dari kayu. Alat musik kentung tidak dapat dipukul oleh tangan atau logam, karena suara yang ditimbulkan akan berubah. Selain itu, akan mempercepat kerusakan pada alat musik kentrung sendiri (Bakir, wawancara pribadi, 27 April 2019). 


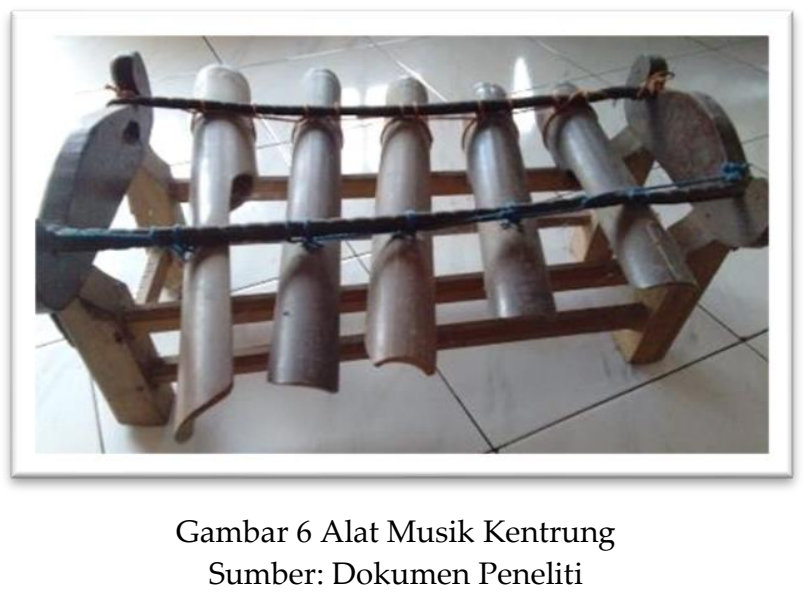

Terbang

Alat musik terbang atau disebut pula rebana atau genjing adalah alat musik berbentuk bundar dan pipih seperti pada gambar 7. Alat musik ini dibingkai dengan membentuk lingkaran dari kayu yang dibubut. Salah satu sisinya berlapis kulit hewan sebagai bagian yang dimainkan dengan cara ditepuk (Bakir, wawancara pribadi, 27 April 2019). Cara memainkan alat musik ini dengan cara dipukul pada bagian membrannya. Lapisan membran terbuat dari kulit hewan, namun ada pula yang terbuat dari seperti plastik. Suara yang dihasilkan alat musik terbang bervariasi tergantung dari ukuran, teknik, dan cara memainkannya. Selain itu, dalam memainkan alat musik terbang, ada beberapa hal yang perlu diperhatikan, antara lain: Pertama, tenaga yang digunakan tidak boleh terlalu kuat dan sebaliknya. Kedua, cara memukulnya pun harus benar agar tangan tidak menjadi sakit. Ketiga, memegang terbang pun harus benar agar suara yang dihasilkan sesuai harapan (Bakir, wawancara pribadi, 27 April 2019).

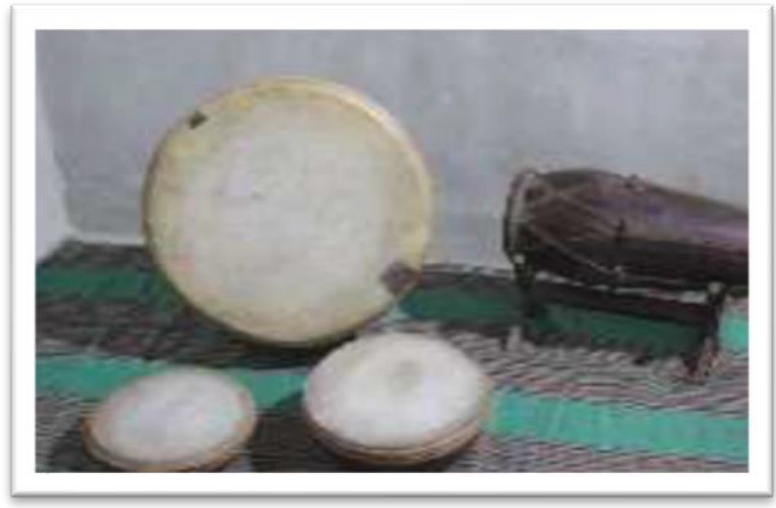

Gambar 7 Alat Musik Terbang yang paling besar di antara Kendang, Kempul, dan Kemprêng Sumber: Dokumen Peneliti

Gong

Gong adalah alat musik yang dimainkan dengan cara dipukul (gambar 8). Namun berbeda dengan gong pada umumnya yang terbuat dari kuningan, pada alat musik tradisional Janengan yang dimaksud gong mirip dengan kempul dan kempréng. Perbedaannya terletak pada ukuran diameternya lebih lebar. Cara memainkan gong pada seni tradisonal Janengan, yaitu dengan cara dimiringkan dipegang dengan tangan kiri. Gunanya agar suara bass dari gong keluar. Telapak tangan kanan memukul bagian pinggir dari membran dan selalu dimainkan mengikuti irama kendang (Fatkhurrohman \& Susetyo, 2017). 


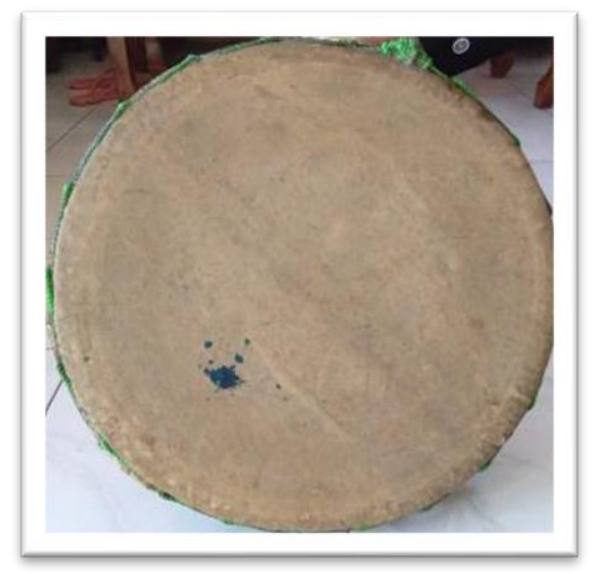

Gambar 8 Alat Musik Gong

Sumber: Dokumen Peneliti

\section{Kecrék}

Kecrék adalah salah satu alat musik yang harus selalu dimainkan dalam seni tradisional Janengan. Dalam bentuknya yang terbaru, kecrék bisa beragam. Namun secara umum, alat musik kecrék terdiri dari beberapa bilah perunggu yang diberi landasan sebuah kayu atau logam lain untuk dipukul-pukul, sehingga berbunyi crék-crék-crék. Fungsinya selain sebagai pemanis permainan musik juga sebagai penanda akan dimulai atau diakhirinya sebuah syi'ir atau singir salawat oleh $k i$ dalang (vokalis) (Bakir, wawancara pribadi, 27 April 2019).

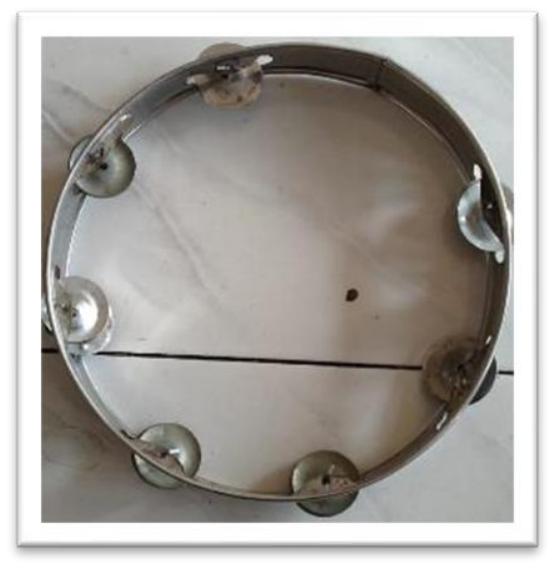

Gambar 9 Alat musik Kecrék

Sumber: Dokumen Peneliti

\section{Unsur Tradisi Jawa-Islam}

Seni tradisional yang kemudian dikenal Janengan dirumuskan dan dibentuk oleh pendirinya, kyai Jamjami dimaksudkan sebagai media syi'ar Islam (dakwah) (Fatkhurrohman \& Susetyo, 2017). Terdapat dugaan, hal itu diilhami oleh wali songo yang berhasil mengadaptasi sastra Jawa Klasik dengan puisi (macapat dan tembang) seperti yang dilakukan Sunan Bonang, syekh Malaya (Sunan Kalijaga), dan Sunan Gunung Djati. Sunan Bonang dianggap berhasil dalam dakwahnya di tanah Jawa melalui kepiawaiannya menyusun sejumlah pupuh yang terangkum dalam Suluk Wujil. Sementara syekh Malaya (Sunan Kalijaga), berhasil dalam syi'arnya di tanah Jawa berkat keberhasilannya mengadaptasi wayang kulit. Sedangkan Sunan Gunung Djati berhasil mengadaptasi seni pertunjukan menjadi sangat islami melalui wayang, barong, topéng, dan ronggéng (Hernawan \& Kusdiana, 2020).

Karena itu, suatu yang tidak begitu mengejutkan dalam seni tradisional buah karya kyai Jamjami. Di samping sarat nuansa agama Islam, meliputi aqidah (tata keimanan, tauhid), dan tasawuf (akhlak, mistisisme), juga kental dengan unsur-unsur keyakinan lokal Jawa yang memadukan beberapa 
keyakinan sebelumnya. Unsur-unsur keyakinan lokal Jawa dimaksud, dalam setiap pementasan seni tradisional Janengan adalah tersedianya sajen (sesaji) (Solihun, wawancara pribadi, 26 April 2019). Sajen tersebut berupa bubur merah dan putih yang dituang dalam mangkok kecil, air kopi dan air teh masing-masing satu gelas, daun sirih, dupa atau kemenyan, minyak wangi, beras, dan air putih seperti pada gambar 10. Semuanya dikumpulkan dalam sebuah baki (wadah) khusus (Solihun, wawancara pribadi, 26 April 2019). Penyajian sajen dimaksudkan sebagai bentuk persembahan, hormat, dan ungkapan rasa terima kasih kepada para leluhur yang telah wafat terlebih dahulu. Para leluhur itu dipercayai semasa hidupnya telah mewariskan ilmu, harta benda, dan lingkungan alam yang terpelihara dengan baik, sehingga masih dapat dinikmati oleh orang-orang yang hidup pada masa kini (Solihun, wawancara pribadi, 26 April 2019).

Dalam pandangan hidup orang Jawa, memuliakan kedua orang tua dan para leluhur merupakan prinsip yang agung. Sebagai orang Jawa yang memelajari kearifan lokal menyadari, bahwa kesuksesan tidak mungkin dapat diraih oleh seorang anak yang tidak hormat dan berbakti kepada kedua orang tua dan leluhur. Untuk itu, sebagai ungkapan rasa hormat dan bakti tidak cukup hanya diucapkan melalui do'a dan pujian, tetapi juga melalui bentuk sajen (Bakir, wawancara pribadi, 27 April 2019).

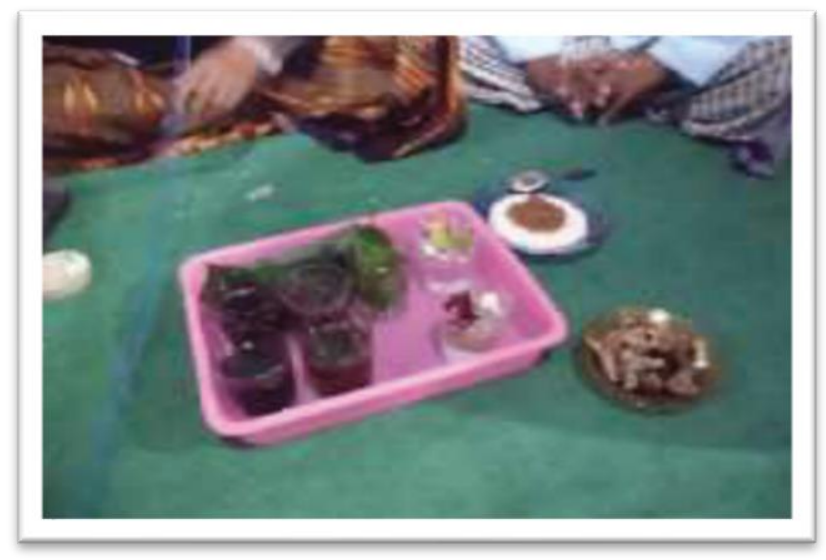

Gambar 10 Sajen yang disajikan Pemain Janengan Sumber: Dokumen Peneliti

Selain dari penggunaan sajen, unsur kearifan lokal lainnya yang dijumpai pada seni tradisional Janengan adalah pengunaan dialek dan nada khas Jawa. Meskipun syi'ir atau singir yang dibawakan mengajarkan ajaran agama Islam, namun khas sastra Jawa Klasiknya masih kental. Tidak jarang pula para seniman seni tradisional Janengan membawakan tembang-tembang macapat dan pupuh yang diciptakan wali songo, seperti: kinanti, dangdanggula, pucung, asmarandana, dan seterusnya (Sodik, wawancara pribadi, 26 April 2019).

Seni tradisional Janengan atau salawat Illau merupakan harmonisasi antara rasam Jawa dan Islam. Kuat dugaan, masyarakat setempat pada masa lalu telah mempunyai kearifan lokal yang kuat. Kearifan lokal masyarakat Jawa, di antaranya terdapat pada: bahasa, kepercayaan, filosofi kehidupan, kesenian, kalender, dan hitungan pasaran (Koenjaraningrat, 1994). Karena itu, para da'i waktu itu memasukan ajaran agama Islam melalui unsur-unsur kearifan lokal. Seni tradisional Janengan, diduga kuat, merupakan salah satu metode da'i dalam hal ini kyai Jamjami dan K.H. Badawi Hanafi dalam syi'ar melalui syi'ir. Masyarakat kelas bawah dahulu yang menurut sejumlah literatur sangat merindukan hiburan (kesenian). Mereka pun lebih mudah menerima ajaran agama yang disampaikan melalui media ini. Nilai-nilai agama yang ada dalam seni Islam menyuguhkan materi hiburan sekaligus menanamkan persepsi dasar tentang Tuhan, alam, dan manusia. Dengan demikian, transmisi ajaran agama Islam dapat diterima lebih mudah. Agama Islam pun sedikit-demi sedikit menjadi keyakinan baru mereka (Matta, 1996).

Unsur ajaran Islam dalam seni tradisional Janengan disusun dalam bentuk syi'ir atau singir salawat berbahasa Arab dengan dialek Jawa. Alat musik yang digunakan pun bernuansa Timur Tengah, yaitu 
sejenis rebana. Namun untuk menghidupkan minat masyarakat, kyai memadukannya dengan kendang yang merupakan alat musik masyarakat setempat. Jadilah perpaduan dua jenis alat musik Islam-Jawa. Itulah seni tradisional Janengan (Solihun, wawancara pribadi, 26 April 2019). Berikut kutipan naskah syi'ir atau singiran salawat Janengan lagu pembuka:

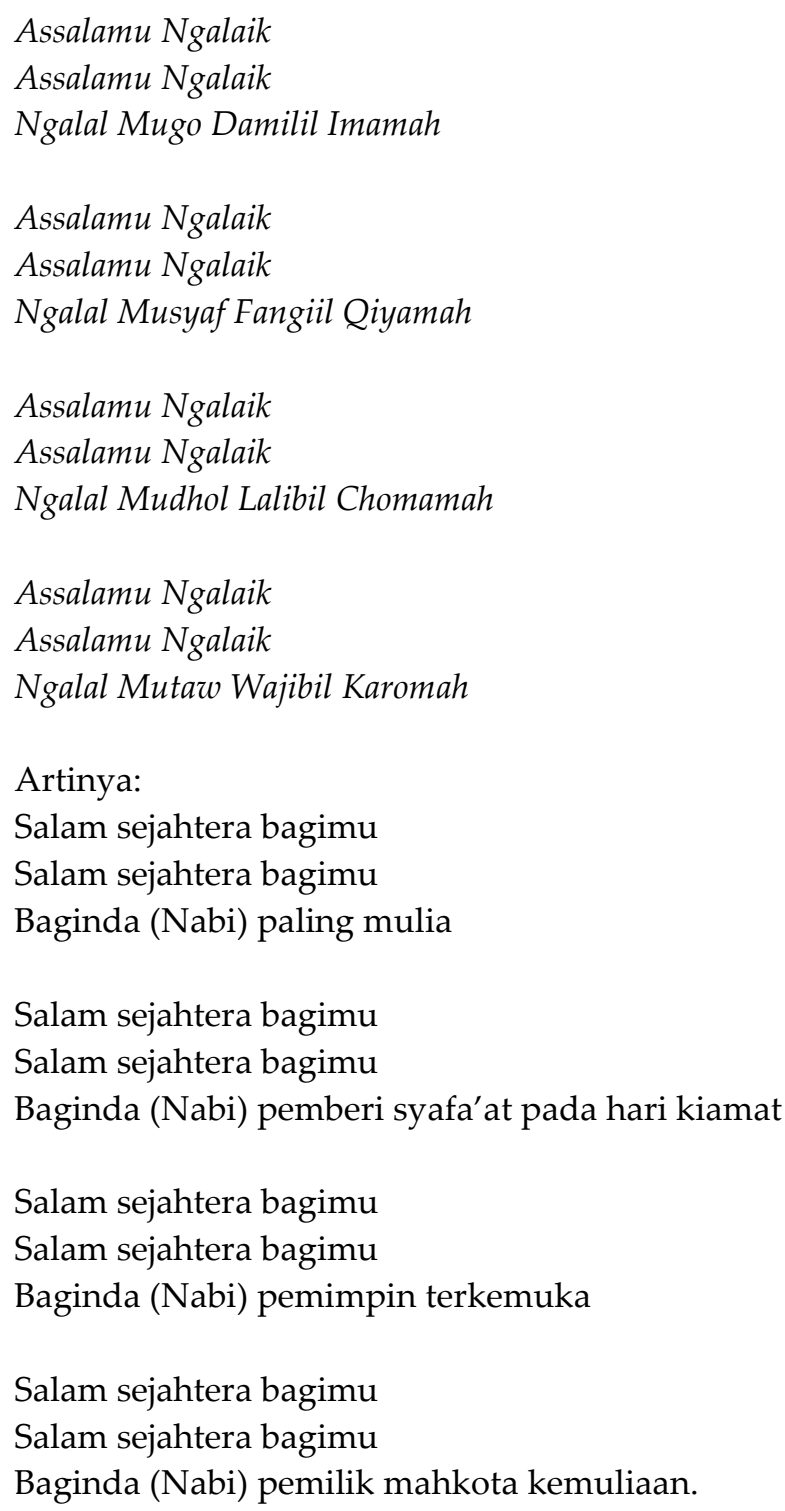

Menurut Sodik (Ketua kelompok seni tradisional Janengan di Desa Kesugihan), lagu-lagu salawat Janengan terdiri dari satu lagu pembuka, delapan belas lagu penyerta, dan satu lagu penutup. Secara keseluruhan lagu-lagu dalam seni tradisional Janengan berisi ajaran tentang aqidah, ritual syari'at, dan Tasawuf yang dikemas dalam ragam budaya lokal Jawa (Sodik, wawancara pribadi, 26 April 2019).

Salah satu contoh singiran lagu Janengan yang berisi ajaran aqidah adalah sebagai berikut:

Laillaha illallah

Lailaha Illallah

Laillaha illallah

Muhammadar Rasullullah

Allah-Allah-Allah Allah Tuhan Allah

Allah-Allah-Allah Robuna

Allah-Allah-Allah Li Hasbuna 


\author{
Allah-Allah-Allah Datullah \\ Allah-Allah-Allah Sifatullah \\ Allah-Allah-Allah Wujudullah \\ Artinya: \\ Tidak ada tuhan selain Allah \\ Tidak ada tuhan selain Allah \\ Tidak ada tuhan selain Allah \\ Muhammad utusan Allah
}

Allah-Allah-Allah Allah Tuhan Allah

Allah-Allah-Allah Pemelihara kami

Allah-Allah-Allah cukuplah Allah Penolong kami

Allah-Allah-Allah Dzat Allah

Allah-Allah-Allah Sifat Allah

Allah-Allah-Allah Wujud Allah

Kandungan dari syi'ir atau singiran di atas memuat dasar-dasar aqidah-Islamiyyah. Lafadz-lafadz seperti itu dikenal dengan Syahadat Tauhid dan Syahadat Rasul atau dikenal pula Jimat Kalimasyada (Gus Toha, wawancara pribadi, 26 April 2019). Sementara itu, dijumpai pula singiran atau syi'ir Janengan berjudul Gobyog Dzikrullah, sebagai berikut:

\title{
E Dzikrullah Allah Allah Dzikrullah \\ Yen Dzikira Siro Maring Gusti Allah \\ E Sirrullah Allah Allah Isirullah \\ E Yola datullah Allah Allah Allah Yola Datullah \\ E Syifatullah Allah Allah Wujudullah \\ E Ulehana Kula Dumateng Dunya \\ E Umahena Kula niki Pinggireng Masjid \\ E Shalat Makmum Shalat Sunat kula Lampahi
}

Artinya:

Ingatlah Allah dengan berdzikir, niscaya Allah ingat kepadamu

Kalau kamu mengingat (Gusti) Allah

Rahasia Allah, Allah rahasia

Dzat-Nya Allah, Allah dengan segala Dzat-Nya

Sifatnya Allah melalui Wujud (keberadaan-Nya) Allah

Berilah saya di dunia ini

Rumah yang bertempat di pinggir masjid

Maka salat yang wajib dan sunat akan aku lakukan.

Apabila dicermati, singiran di atas berisi anjuran untuk senantiasa dzikir (mengingat) Allah Swt., dalam keadaan lapang atau pun sempit. Dzikir dimaksud tidak lain adalah beribadah hanya kepada Allah Swt. (Fatkhurrohman \& Susetyo, 2017). Pesan lain yang terkadung dalam singiran itu adalah anjuran untuk selalu bersalawat kepada Nabi Saw., agar kelak di akhirat mendapatkan syafa'at-nya 
(Fatkhurrohman \& Susetyo, 2017). Singiran lain yang berisi anjuran agar senantiasa mengingat Allah Swt., dengan dzikir dijumpai pada syi'ir Yo Elingo, sebagai berikut:

E Yo Elingo Sira, Sira Eling Maring Pangêran

Yola Sira Pada Eling Fardu Sunnat Sira lakonono

E Elinga Umat kanjeng Nabi

Kabeh Mumpung. Kabeh Mumpung Neng Ngalam Dunya

Yola pada Ngaji Sira Ginawr Sangu

Gawe Sangu Maring Siwarga

E Yo Elinga Sira Maring Pangêran

Sira Manungsa Mumpung Aneng Ngalam Dunya

Lamun Sira Sira Ora Eling

Sira Manungsa Aneng Kubur Dipun Siksa (Rohmah, 2019).

Terjemah:

Ingatlah kamu, ingatlah kamu kepada Pangêran (Tuhan)

Ayolah kamu ingat untuk melaksanakan perbuatan wajib dan sunat

Sebagai umat Kanjeng Nabi ingatlah kamu

Selagi kamu masih berada di alam dunia

Mengajilah kamu untuk bekal

bekal kamu kelak ke Surga

Ingatlah kamu kepada Pangêran (Tuhan)

Sebagai manusia selagi hidup di alam dunia

Kalau kamu tidak ingat sebagai manusia

Kelak kamu di alam kubur akan disiksa (Rohmah, 2019).

\section{Kesimpulan}

Sejumlah pendekatan digunakan para da'i dalam penyebaran agama Islam di bumi Jawa. Tidak terkecuali kyai Jamjami dari Kebumen, yang dilanjutkan oleh K.H. Badawi Hanafi, hingga putranya, K.H. Mustholih Badawi dari Pondok Pesantren Al-Ihya Ulumaddin Kesugihan Cilacap. Suatu yang menarik, di antara sejumlah pendekatan itu, diawali oleh Kyai Jamjami menjadikan seni tradisional Jawa-Islam yang kemudian dikenal Janengan atau salawat Janengan sebagai pilihan. Ia mengajarkan ajaran agama Islam, mulai dari akidah (tata keimanan, tauhid) hingga tasawuf (mistisisme Islam) melalui syi'ir atau singiran yang diiringi tabuhan alat musik rebana (khas Timur Tengah) dan kendang (khas Jawa). Pada saat yang sama, unsur budaya lokal terutama dalam bahasa, kepercayaan, dan kesenian lokal digunakannya. Hasilnya, sampai hari ini masih dapat disaksikan keindahan seni tradisional Janengan meskipun dalam hal-hal tertentu berbau sikretisme. Rasa hormat dan bakti kepada leluhur yang diwujudkan pada sajen masih menghiasi setiap pementasan seni tradisional Janengan. Seni tradisional itu, khusus di Desa Kesugihan Kecamatan Kesugihan Kabupaten Cilacap masih menjadi pilihan masyarakat, terutama pada Perayaan Hari Besar Islam (PHBI) maupun slametan keluarga.

\section{Referensi}

Ahmed, I. (2015). Lagu melayu asli: unsur sinkretisme dalam instrumentasi persembahan. Jurnal Melayu, 14(2).

Aldyan, R. A. (2020). Community's Syncretism on Sunan Kudus Teaching. Journal of Economic Tropical Life Science, 4(2), 38-45. https://doi.org/10.21428/e61c265e.aa82d6df

Amin, M. D. (Ed.). (2000). Kebudayaan Jawa. Yogyakarta: Gama Media.

Anggoro, B. (2018). “Wayang dan Seni Pertunjukan” Kajian Sejarah Perkembangan Seni Wayang di Tanah Jawa sebagai Seni Pertunjukan dan Dakwah. JUSPI (Jurnal Sejarah Peradaban Islam), 2(2), 122. 
https://doi.org/10.30829/j.v2i2.1679

Bahardur, I. (2018). Kearifan Lokal Budaya Minangkabau dalam Seni Pertunjukan Tradisional Randai. Jentera: Jurnal Kajian Sastra, 7(2), 145-160.

Brakel, L. F. (2004). Islam and local traditions: syncretic ideas and practices. Indonesia and the Malay World, 32(92), $5-20$.

Fatkhurrohman, A., \& Susetyo, B. (2017). Bentuk Musik dan Fungsi Kesenian Jamjaneng Grup Sekar Arum di Desa Panjer Kabupaten Kebumen. Jurnal Seni Musik, 6(1), 1-12.

Fauzan, R., \& Nashar, N. (2017). Mempertahankan Tradisi, Melestarikan Budaya (Kajian Historis dan Nilai Budaya Lokal Kesenian Terebang Gede di Kota Serang). Candrasangkala: Jurnal Pendidikan Dan Sejarah, 3(1), 1-9.

Fitrianto, F. (2017). Kesenian Janengan: Identitas Keetnisan Masyarakat Jawa di Pajaresuk Lampung. INVENSI (Jurnal Penciptaan Dan Pengkajian Seni), 2(1), 27-39.

Habibi, H. (2016). Peran Ki Dalang Basari (1950-2003) dalam Perkembangan Islam di Gegesik Cirebon. Jurnal Tamaddun: Jurnal Sejarah Dan Kebudayaan Islam, 1(2).

Hasan, R. (2013). Seni Seudati: Media Edukasi Sufistik dalam Mengembangkan Nilai Socio-Religius Masyarakat Aceh. Al-Tahrir: Jurnal Pemikiran Islam, 13(1), 151-170.

Hernawan, W. (2014). Seabad Persatuan Ummat Islam (1911-2011). Bandung: Yayasan Masyarakat Sejarawan Indonesia (YMSI) Cabang Jawa Barat dan PUI Jawa Barat.

Hernawan, W., \& Kusdiana, A. (2020). Biografi Sunan Gunung Djati: Sang Penata Agama di Tanah Sunda. Bandung: LP2M UIN Sunan Gunung Djati Bandung.

Irianto, A. M. (2016). Komodifikasi budaya di era ekonomi global terhadap kearifan lokal: Studi kasus eksistensi industri pariwisata dan kesenian tradisional di Jawa Tengah. Jurnal Theologia, 27(1), 212-236.

Junaidi, A. A. (2013). Janengan sebagai seni tradisional Islam-Jawa. Walisongo, 21(2), 469-490.

Koenjaraningrat. (1994). Kebudayaan Jawa. Jakarta: Balai Pustaka.

Kraemer, H. (1954). Syncretism as A Religious and a Missionary Problem. International Review of Mission, 43(3), 253-273.

Lindsay, L., \& Kitsch, K. (1991). Kontemporer: Sebuah Studi tentang Seni Pertunjukan Jawa. Yogyakarta: Gadjah Mada University Press.

Martin, L. H. (1996). Syncretism, historicism, and cognition: A response to Michael Pye1. Method E Theory in the Study of Religion, 8(2), 215-224.

Matta, M. A. (1996). Seni Islam: Format Estetika dan Muatan Nilai. Jakarta: Yayasan Festifal Istiqlal.

Miharja, D., \& Hernawan, W. (2017). Merawat Kerukunan di Desa Cikawungading, Kecamatan Cipatujah, Kabupaten Tasikmalaya, Jawa Barat. Religió: Jurnal Studi Agama-Agama, 7(2), 297-319.

Mulder, N. (1999). Agama Hidup Sehari-hari dan Perubahan Budaya. Jakarta: Gramedia Pustaka Utama.

Murtana, I. N. (2011). Afiliasi Ritus Agama dan Seni Ritual Hindu Membangun Kesatuan Kosmis. Mudra, 26(1), 61-69.

Pamadhi, H. (2012). Pendidikan Seni. Yogyakarta: UNY Press.

Purnata. (1977). Sekitar Perkembangan Seni Rupa di Bali. Denpasar: Proyek SasanaBudaya Bali.

Purwanto, S. (2016). Pendidikan Karakter Melalui Seni. Yogyakarya: Penerbit Pustaka Pelajar.

Rochsun, R. (2018). Musik Tradisional Jawa Janengan Yang Terlupakan (A Forgotten Javanese Traditional Music Janengan). Paradigma: Jurnal Filsafat, Sains, Teknologi, Dan Sosial Budaya, 24(2), 9-18.

Rohmah, A. (2019). Sinkretisme dalam Tradisi Seni Musik Tradisional Janengan sebagai Identitas Masyarakat Islam-Jawa di Desa Kesugihan Kecamatan Kesugihan Kabupaten Cilacap Jawa Tengah. UIN Sunan Gunung Djati Bandung.

Said, H. A. (2016). Islam dan Budaya di Banten: menelisik tradisi debus dan maulid. Kalam, 10(1), 109-140.

Saihu, S. (2020). Local Tradition and Harmony among Religious Adherents: the Dominant Culture of HinduMuslim Relation in Jembrana Bali. Wawasan: Jurnal Ilmiah Agama Dan Sosial Budaya, 5(1), 31-42. https://doi.org/10.15575/jw.v5i1.8029

Sarwono, R. (2017). Konsep Seni pada Karya Seni Lukis Anak Usia 4 sampai 8 Tahun. Waspada (Jurnal Wawasan Pengembangan Pendidikan), 2(2), 84-102.

Sulastri, I. (2014). Nilai-Nilai Islam Dalam Seni Tradisional Debus Di Menes Pandeglang Banten. UIN Syarif Hidayatullah Jakarta.

Supatmo, S. (2016). Keragaman Seni Hias Bangunan Bersejarah Masjid Agung Demak. Imajinasi: Jurnal Seni, 10(2), 107-120.

Supatmo, S., \& Syafii, S. (2019). Nilai Multukultural Ornamen Tradisional Masjid-Masjid Warisan Para Wali di Pesisir Utara Jawa. Imajinasi: Jurnal Seni, 13(2), 1-14.

Sutisna, R. H., Suganda, D., Dienaputra, R. D., \& Guna, B. W. K. (2019). Sinkretisme pada Pertunjukan Seni Gamelan Koromong Kampung Cikubang Rancakalong Kabupaten Sumedang. Gondang: Jurnal Seni Dan Budaya, 3(1), 20-34. 
Syarfina, T. (2011). Sinkretisme dalam Jampi Melayu Deli: Tinjauan Transformasi Budaya. Atavisme, 14(1), $29-40$. Taman, M., \& Maqosid, Y. (2008). Keajaiban Hari Jum'at: Menyingkap Rahasia dan Keistimewaan Jum'at sebagai Sayyidul Ayyam. Yogyakarta: Pustaka Al-Kautsar.

Wahyono, S. B. (2001). Kejawaan Dan Keislaman: Satu Pertarungan Identitas. Jurnal Ilmu Sosial Dan Ilmu Politik, 5(1), 41-59.

(C) 2020 by the authors. Submitted for possible open access publication under the terms and conditions of the Creative Commons Attribution (CC BY SA) license (https://creativecommons.org/licenses/by-sa/3.0/). 